\title{
1 An Antioxidant Polysaccharide from Ganoderma lucidum Induces 2 Apoptotic Activity in Breast Cancer Cell Line
}

3 Md. Moyen Uddin $\mathrm{Pk}^{1,2}$, Rumana Pervin ${ }^{3}$, Mohammad Shahangir Biswas ${ }^{3}$ and Md. Matiar

4 Rahman $^{3 *}$

$5 \quad{ }^{1}$ Institute of Biological Science, Rajshahi University, Bangladesh

$6 \quad$ Independent University of Bangladesh, Bangladesh

$7 \quad$ BBiochemistry \& Molecular Biology, Rajshahi University, Bangladesh

\section{Abstract}

The purpose of this study is to elucidate the apoptotic activity of Ganoderma lucidum polysaccharide (GLP) in a human breast cancer cell line MCF-7 in vitro. According to DPPH assay, GLP showed a good antioxidant ( $\mathrm{IC}_{50}$ value is $\left.202.4 \mu \mathrm{g} / \mathrm{mL}\right)$. Based on MTT assay, the results showed that GLP inhibits MCF-7 cells proliferation in a dose- and time- dependent manner $(\mathrm{p}<0.001)$. $\mathrm{IC}_{50}$ values of the cytotoxicity of GLP and doxorubin were $110.907 \mu \mathrm{g} / \mathrm{mL}$ and $58.206 \mu \mathrm{g} / \mathrm{mL}$ respectively. The results from the flow cytometry indicated that GLP could induce apoptotic activity through inducing the up-regulation of the Bax and Caspase- 9 and the down-regulation of the BcL-2 in MCF-7 cells. At $2 \times \mathrm{IC}_{50}$, GLP increased the early-apoptotic and dead cells of MCF-7 from $18.23 \%$ to $34.76 \%$ and $8.45 \%$ to $16.34 \%$ respectively. In conclusion, the GLP shows anticancer activity against MCF-7 through preventing the proliferation and inducing the apoptosis of MCF-7 cells. Our data provide the potential molecular targets in cancer prevention and reveal the key barriers in the current anticancer drugs development.

Keywords: Polysaccharide; Antioxidants; Apoptosis; Breast cancer; Western blot 


\section{Introduction}

Breast cancer is the leading cause for women's mortality in the world(1). Nearly one quarter of female cancer patients are diagnosed with breast cancer(2). When breast cancer progresses, cancer cells release antiapoptotic factors. Breast cancer continues to be a major concern and threat to human health (3). The treatment options are limited by various subtypes of breast cancer, each requiring different therapy regimens. Chemotherapy and radiotherapy are the standard treatment for breast cancer; however, the treatment results are mostly disappointing for patients. In this situation it is important to explore various alternative therapies for the treatment of breast cancer. In many cultures it is popular to use herbs to treat malignancies, as there are the plenty of anti-cancer compounds in some plants and are used in the manufacture of various modern drugs(4). Different sources of polysaccharides for their anti-cancer activities have been identified $(5,6)$. Through its possible biological functions, antioxidant(7), anti-tumor(8) and hepatoprotective effects(9), polysaccharides have attracted a lot of attention. Several studies showed that biologically active compounds isolated from mushrooms are primarily linked to polysaccharides for the anti-cancer properties(10-14). Previous researches have shown that polysaccharides isolated from the Ganoderma lucidum show antitumor properties(15). As far as we know, no research on the anti-tumor activities of Ganoderma lucidum polysaccharide on MCF-7 cells was conducted in Bangladesh. This study aimed to investigate the antitumor effects of Ganoderma lucidum polysaccharide (GLP) on MCF-7 cells in vitro models. This study was intended as a scientific basis for work on polysaccharide and for the application in medicine. The data support the potential use of GLP for the treatment of breast cancer. 


\section{MATERIALS AND METHODS}

54

55

56

57

58

59

60

61

62

63

64

65

66

67

68

69

70

71

72

73

74

75

76

77

78

79

80

\section{Chemicals}

All culture media including RPMI-1640, fungizone, FBS, and penicillin-streptomycin solution, DEAE, DPPH, ABTS, MTT, Tris, DTT, SDS, DCFH-DA, ethanol, acetone, and sulfuric acid were obtained from Sigma-Aldrich, USA. All other chemicals including KBr, butanol, chloroform, phenol, EDTA, trypsin, ether, glycerol, hydrogen peroxide were purchased from Merck, Germany. In addition, FITC/PI, Bcl-2, Bax, Cas-9 and colorimetric assay kits were obtained from Abnova, Germany. Western blot antibodies against Bax, Bcl-2 and Caspase-9 were purchased from Abnova (Germany), CST (Boston, MA), SCB ( Stanta cruz, CA) respectively.

\section{Sample collection}

Fruiting bodies of Ganoderma lucidum were collected from the Mushroom Development Institute, Bangladesh. It was authenticated by Scientific officer at National Mushroom Development and Extension Center, Savar, Dhaka-1340 in Bangladesh. No.: SR-0022(2/3/2018)

\section{Extraction}

Polysaccharide from the Ganoderma lucidum (GL) fruiting bodies was extracted according to the methods of our previously published article 9 . In short, the dried powder $(30 \mathrm{~g})$ of the Ganoderma lucidum (PO) was extracted with distilled water $(1: 30)$ at $90^{\circ} \mathrm{C}$ for $3 \mathrm{~h}$ under stirring to remove hot water dissolved pigments, polyphenols, and monosaccharides. The liquid fraction was collected by centrifugation at $5000 \mathrm{rpm}$ for $15 \mathrm{~min}$ at $56^{\circ} \mathrm{C}$ and precipitated with $95 \%$ ethanol $(1: 3, \mathrm{v} / \mathrm{v})$ for $12 \mathrm{~h}$ at $4^{0} \mathrm{C}$. Precipitates were observed and collected by centrifugation (4500 rpm for $20 \mathrm{~min}$ at $\left.4^{\circ} \mathrm{C}\right)$ and washed consecutively with acetone (1:3 v/v, 95\%), ether (1:3 $\mathrm{v} / \mathrm{v}, 95 \%)$, and ethanol $(1: 3 \mathrm{v} / \mathrm{v}, 95 \%)$ at $4^{\circ} \mathrm{C}$. The precipitate was dried in vacuum to obtain protein-bound Polysaccharide (PBP). The total protein content and the total polysaccharides content were quantified by the Lowry method (16) and phenol-sulfuric acid method(17) respectively. 


\section{Protein free polysaccharide isolation}

82 GLP crude extract was deproteinated using Sevag method(18). According to Sevag principle, the 83 sample and Sevag reagent ratio was 2:1(Chloroform:n-Butanol, 5:1). The optimized ratio of GLP to Sevag reagent was $2: 1$.

Deproteination rate $(\%)=\left[\left(\mathrm{P}^{\mathrm{c}} \mathrm{O}-\mathrm{P}^{\mathrm{c}} \mathrm{a}\right) / \mathrm{P}^{\mathrm{c}} \mathrm{o}\right] \mathrm{x} 100$ deproteinization

Polysaccharide Loss rate $(\%)=\left[\left(\mathrm{A}_{\mathrm{o}}-\mathrm{A}_{\mathrm{a}}\right) / \mathrm{A}_{\mathrm{o}}\right] \times 100$

where $\mathrm{A}_{\mathrm{o}}$; polysaccharide content before deproteinization, $\mathrm{A}_{\mathrm{a}}$; polysaccharide content after deproteinization

After deproteinization, the solution was desalinated with hyperfiltration $(3 \mathrm{Kda}, 5.0 \mathrm{~mL} / \mathrm{min}$ for $8 \mathrm{~h}$ ) and the filtrate was mixed with $99.5 \%$ ethanol and the mixture was kept at $4^{\circ} \mathrm{C}$ for $24 \mathrm{~h}$. After centrifugation $\left(4000 \mathrm{rpm}, 4^{\circ} \mathrm{C}\right.$ for $\left.15 \mathrm{~min}\right)$, the precipitate was dissolved in $\mathrm{dH}_{2} \mathrm{O}$ and then lyophilized in a vacuum freeze dryer to obtain the crude polysaccharide, GLP. The standard curve was constructed using D-glucose $\left(\mathrm{C}_{6} \mathrm{H}_{12} \mathrm{O}_{6}\right)$ and the linearity of standard curve and $\mathrm{Y}=0.6965^{*} \mathrm{X}+0.1767,\left(\mathrm{R}^{2}=0.9918, \mathrm{p}<0.001\right)$

where Y represents the absorbance; X represents the GLP content (mg/mL). where X represents the GLP content (mg); W represents the weight of the mushroom powder (g).

\section{Purification of polysaccharide by chromatographic methods}

DEAE-Ion exchange chromatography and gel filtration chromatography (GFC) were used to remove fine particles from crude GLP.The crude polysaccharide was loaded onto DEAE-52

105 column $(2.6 \mathrm{X} 80 \mathrm{~cm})$ and the stage gradient elution was carried out using $\mathrm{dH}_{2} \mathrm{O}, 0.2 \mathrm{M} \mathrm{NaCl}$, and 
107 checked in each $5 \mathrm{~mL}$ test tubes using the phenol-sulfuric acid supplementary method. The

108 largest polysaccharide content fractions were combined, collected and loaded onto Sephadex S-

109300 column $(1.6 \times 100 \mathrm{~cm})$ and equilibrated with $0.05 \mathrm{M} \mathrm{NaCl}$. The elution flow rate was 24

$110 \mathrm{~mL} / \mathrm{hr}$. The largest fraction was collected and desalted against $\mathrm{ddH}_{2} \mathrm{O}$ over 5 days using dialysis

111 membrane having a 14000 Da MWCO (Thermo Fisher Scientific). After dialysis, the

112 polysaccharide solution was concentrated and lyophilized to obtain refined polysaccharide.

113 Relative molecular weight determination using GFC

114 Molecular weights of the GLP fraction was determined using Sepharose CL-6B in comparision

115 to the molecular weights of known dextran series $(10-2000 \mathrm{kDa}, 10 \mathrm{mg} / \mathrm{mL})$. The standard curve 116 was used to calculate Mw of GLP and this curve was constructed at Mw vs $\mathrm{K}_{\mathrm{av}}$. The $\mathrm{K}_{\mathrm{av}}$ was

117 calculated using the following formula:

$118 \mathrm{~K}_{\mathrm{av}}=(\mathrm{Ve}-\mathrm{Vo}) /(\mathrm{Vt}-\mathrm{Vo})$

119 where Vt; total column volume, Ve; elution volume, Vo; void volume, and $\mathrm{K}_{\mathrm{av}}$; proportion of 120 pores available to the molecule.

121 The linearity of the standard curve was evaluated with $\mathrm{R}^{2}$ value. $\mathrm{R}^{2}$ value explains the significant 122 correlation between dependent $\left(\mathrm{K}_{\mathrm{av}}\right)$ and independent variables (Mw of dextrans).

123 Spectroscopic analysis of polysaccharide

\section{UV-vis spectroscopic analysis}

125 GLP was dissolved in distilled water (upto 5\%) and were analyzed at 200-600 nm using 126 spectrophotometer (Double beam UV-visible light spectrophotometer, China). In this analysis, 127 the protein and carbohydreate contents were determined.

\section{Fourier transform infrared analysis}

130 The fourier transform infrared (FT-IR) method was used to determine the organic functional 131 group of polysaccharide. Before grinding with $\mathrm{KBr}$ powder, GLP (3 mg) was dried at $40-45^{\circ} \mathrm{C}$ 132 and then pressed into a pellet $(1 \mathrm{~mm})$ for spectrometer measurement. The wavelength was set by 133 a resolution of $8 \mathrm{~cm}^{-1}$ from 4000 to $400 \mathrm{~cm}^{-1}$ at $25^{0} \mathrm{C}$. 


\section{Monosaccharide composition}

135

136

137

138

139

140

141

142

143

144

145

146

147

148

149

150

151

152

153

154

155

156

157

158

159

160

161

In this experiment, polysaccharide was hydrolyzed with $2 \mathrm{M}$ TFA $(2 \mathrm{~mL})$ at $120^{\circ} \mathrm{C}$ for $3 \mathrm{~h}$. After removing excess TFA, hydrolysate was collected and dissolved in ultrapure water $(4 \mathrm{~mL})$ and the mixture was reduced with $\mathrm{NaBH}_{4}(40 \mathrm{mg})$ at $25^{\circ} \mathrm{C}$. After $3 \mathrm{~h}$, the mixture was neutralized with acetic acid (25\%), and was evaporated the solution with rotary evaporator. At $100^{\circ} \mathrm{C}$, acetic anhydrate $(3 \mathrm{~mL})$ and pyridine $(3 \mathrm{~mL})$ were added in each sealed reaction tube and was kept for $1 \mathrm{~h}$. Standard monosaccharides (D-Mannose, D-Glucose and D-Galactose) were prepared in the same procedure. The solutions were analyzed with an Agilent $6890 \mathrm{GC}$ ( Column HP-5, $30 \mathrm{~m} \mathrm{x}$ $0.32 \mathrm{~mm})$.

\section{Cell lines}

The MCF-7 and MCF-10a cells were obtained from ATCC ( American Type Cell Culture Collection), Manassas, USA. The MCF-7 cells were cultured in RPMI-1640 (Sigma, USA) while MCF-10a cells were maintained in Ham's F-12 (Sigma, USA) and Dulbecco's modifed eagle medium supplemented with EGF $(20 \mathrm{ng} / \mathrm{mL})$, Insulin $(10 \mu \mathrm{g} / \mathrm{mL})$ and hydrocortisone (250 $\mathrm{ng} / \mathrm{mL})$. All media were added with $0.5 \%$ Fungizone, 10\% FBS and $2 \%$ penicillin and streptomycin $(100 \mathrm{ng} / \mathrm{mL})$. The cells were incubated at $37^{\circ} \mathrm{C}$ in $90 \%$ humidifed incubator with $5 \% \mathrm{CO}_{2}$ and, after reaching $80 \%$ confluence, cells were harvested using $0.25 \%$ trypsin-EDTA. The stock solution was prepared in $0.1 \% \mathrm{DMSO}$ and processed at $-20^{\circ} \mathrm{C}$ before use.

\section{DPPH radical-scavenging assay}

The $\mathrm{DPPH}^{+}$radicals scavenging assay described by Nithianantham et al (19) and Uddin Pk et al (10)was used to determine the antioxidant activity of GLP. In short, $50 \mu \mathrm{L}$ samples $(31.25$ to $1000 \mu \mathrm{g} / \mathrm{mL})$ were added in reaction tube and following DPPH $(0.004 \%$, w/v) was added in each reaction tube. After vortex properly, the mixtures were incubated at $25^{\circ} \mathrm{C}$ for $30 \mathrm{~min}$ in dark place. In this experiment, the blank, the DPPH control, and the positive control were $80 \%$ ethanol, $0.004 \%$ DPPH, and vitamin C respectively. The discoloration of reaction in each tube was measured at $517 \mathrm{~nm}$ and measurements were taken in three times. DPPH radicals scavenging by extracts and vitamin $\mathrm{C}$ was determined using the following formula: 
DPPH radicals scavenging effect $(\%)=\frac{(A 0-A)}{A 0} \times 100$

163

164

165

166

167

168

169

170

171

172

173

174

175

176

177

178

179

180

181

182

183

where A0 represents the absorbance of negative control and A represents the absorbance of samples. Results of vitamins $\mathrm{C}$ and GLP were reported as $\mathrm{EC}_{50}$ using linear regression analysis.

In the EPR analysis, the reaction mixtures were loaded to capillary tubes for the EPR spectrometry ( E500, Bruker, USA) and the EPR signals were recorded (60s) with the following EPR measurement conditions: central field $3505 \pm 50 \mathrm{~g}$, modulation frequency $100 \mathrm{kHz}$, modulation amplitude $2.0 \mathrm{~g}$, microwave power $1.02 \mathrm{~mW}$, gain $65 \mathrm{~dB}$, scan time $20.97 \mathrm{~s}$ and time constant $40.96 \mathrm{~ms}$

\section{Cytotoxicity assay}

GLP and doxorubicin (Sigma, USA) were dissolved in DMSO (Sigma, USA) to make a stock solution $(1 \mathrm{mg} / \mathrm{mL})$ and stored in $-20{ }^{\circ} \mathrm{C}$ before use. The working solution was freshly prepared in the complete culture medium. In cytotoxicity study, the MCF-7 cells was seeded at 5 $\times 10^{3}$ cells/ well $(200 \mu \mathrm{l})$ into a 96-well plate overnight in $95 \%$ humiditiy and $5 \% \mathrm{CO}_{2}$. After $24 \mathrm{~h}$ the cells were incubated with GLP(10 to $1000 \mu \mathrm{g} / \mathrm{mL})$, negative control, positive control Doxorubin was used as positive control (48 $\mathrm{h}$ of incubation). The cells were rinsed with $1 \times$ PBS. And then, $20 \mu \mathrm{l}$ MTT $(5 \mathrm{mg} / \mathrm{ml})$ was added to each well and mixed properly. After $2 \mathrm{~h}$ incubation, the dark blue formazan crystals were separated and $100 \mu$ of DMSO was added to dissolve crystals at $37^{\circ} \mathrm{C}$ for $30 \mathrm{~min}$. All measurements were taken in three times.

Finally, the absorbance was measured at $570 \mathrm{~nm}$ using microplate reader (Molecular Devices, USA) and the cell viability (\%) was calculated using the following equation:

$\%$ Cell viability $=\frac{\text { Abs. of treated cells }}{\text { Abs. of untreated cells }} \times 100$ 


\section{Study of cell apoptosis}

189

190

191

192

193

194

195

196

197

198

199

200

201

202

203

204

205

206

207

208

209

210

211

212

213

214

215

GLP-induced apoptosis was performed by FACS calibur flow cytometer (BD Bioscience, USA). MCF-7 cells $\left(1 \times 10^{5}\right)$ were seeded in well culture plates and kept overnight. Following day the medium was replaced with new culture medium and cells were treated with GLP $\left(2 \times \mathrm{IC}_{50},\right)$ for 48 h. The treated cells were harvested and washed with PBS twice. The cell pellets were re-suspended in binding buffer $(500 \mu \mathrm{L})$ and stained with Annexin V-FITC and PI using a Dead Cell Apoptosis Kit (Invitrogen) according to the manufacturer's instruction. After 20 minute incubation at $25^{\circ} \mathrm{C}$ in the dark, cells were analyzed.

\section{Cell cycle analysis}

Cell cycle phase distribution of MCF-7 cell was evaluated by measuring the DNA content. In this experiment, the treated and untreated cells were trypsinised and washed with $\mathrm{PBS}$. At $4^{\circ} \mathrm{C}$, cells were fixed in 70\% ice cold ethanol for overnight and washed with PBS to remove residual ethanol. Cells were re-suspended in $300 \mu \mathrm{l}$ of PBS containing propidium iodide (50 $\mu \mathrm{g} / \mathrm{ml}), 0.5 \%$ Triton X-100 and RNAse A $(50 \mu \mathrm{g} / \mathrm{ml})$ and incubated in water bath at $37{ }^{\circ} \mathrm{C}$ for 30 min. Cells were analyzed for cell cycle distribution at different phases $(\mathrm{G} 0 / \mathrm{G} 1, \mathrm{~S}$, G2/M and sub-G1) in FACS Calibur flow cytometer (BD Biosciences, USA).

\section{Analysis of the mitochondrial membrane potential using the cationic JC-1 dye}

In this experiment, previously cultured MCF-7 cells were treated with GLP and incubated for 48 h. Then, cells were treated with JC 1 ( $20 \mu 1$ of $200 \mu 1$ JC 1$)$ for 15 minutes at $37^{\circ} \mathrm{C}$. The cells were centrifuged for $5 \mathrm{~min}$ at $25^{\circ} \mathrm{C}$ at $400 \times \mathrm{g}$. The cell pellets were washed and re-suspended with PBS. The green JC -1 monomers in mitochondria of apoptic MCF- 7 cells was detected in the FL1 channel (FITC, GFP), while the red aggregates of JC-1 in non-apoptotic cells were detected in the FL2 channel (PE, R PE, RD1).

\section{Apoptotic protein expression analysis}

Apoptotic proteins expression were analyzed using Western blot(11). In this assay, cells were treated with GLP for $48 \mathrm{~h}$ and harvested and lysed with assay buffer ( Tris $62.5 \mathrm{mM}, \mathrm{pH} 6.8$, DTT 50 mM, 10\%SDS, glycerol; Thermo Fisher Scientific, USA). Proteins were extracted and quantified using Bradford assay and separated by 15\% SDS-PAGE and transferred onto a 
216 polyvinylidene fluoride membrane at $4^{0} \mathrm{C}(100 \mathrm{~V})$. After $2 \mathrm{~h}$, the membrane was probed with

217 primary antibody (1:1000) and followed by secondary antibody (HRP; 1:8000). Protein bands were detected by Enhanced chemiluminescence detection kit (Thermo Fisher Scientific, USA).

\section{Statistical analysis}

220

GraphPad Prism was used for statistical analysis. The data are shown as the mean \pm s.d. In order to perform statistical comparisons one-way analysis of variance was used. Effective doses were expressed as $\mathrm{IC}_{50}$ values of polysaccharide. A statistically significant difference was known to suggest $\mathrm{P}<0.05$ between the values.

\section{RESULTS}

\section{Polysaccharide purification and molecular weight determination}

227 Polysaccharide extraction from Ganoderma lucidum was carried out using hot-water extraction technique. . The validation of the phenolic-sulfuric acid method was carried out using standard D-glucose and the maximum absorbance of D-glucose was recoreded at $490 \mathrm{~nm}$ and the linearity 230 of standard curve was $99.18 \%(\mathrm{p}<0.001)$ (Fig. 1). extraction. In figure 2, three fractions ( F1, F2, and F3) were found by ion exchange chromatography (DEAE-52) and GLP was purified on Sephadex S-300 column. weight of GLP was 159498.8 (Da) using standard curve (Fig. 3).

\section{UV-Viz and FTIR analysis}

238 In UV-Viz analysis, the crude GLP fraction had protein $(280 \mathrm{~nm})$ impurity (Fig. 4A) and after 239 deproteination, there was no absorbance at $280 \mathrm{~nm} / 260 \mathrm{~nm}$. Fig. 4B indicates that the GLP was 240 free from protein and nucleic acids.

241 FT-IR spectroscopy was used to identify characteristic functional groups of purified GLP. FT-IR 
the characteristic absorbance at about $3419.8 \mathrm{~cm}^{-1}, 2924.5 \mathrm{~cm}^{-1}$, and $1615.1 \mathrm{~cm}^{-1}$ for $-\mathrm{OH}$ groups, $\mathrm{C}-\mathrm{H}$ bond, and $\mathrm{C}=\mathrm{O}$ bond respectively. The spectra at $990-1050 \mathrm{~cm}^{-1}$ confirmed the presence of $\beta$-glycosidic linkage. The main chain of polysaccharide is $\alpha$-D-glucopyranose..

\section{Monosaccharides compositions}

GLP was homopolysaccharides composing of D-glucose. Figure $5 \underline{5}$ (A, B) shows the GC results of standard momosaccharides and GLP.

\section{Antioxidant activity screening}

Antioxidant activity was performed with the DPPH free radicals scavenging assay. Figure 6(A) and 6(B) illustrate \% antioxidant activity of GLP. The $\mathrm{IC}_{50}$ alue of GLP was $202.4 \mu \mathrm{g} / \mathrm{mL}$. It was concentration dependent activity. The highest concentration of GLP showed the maxiummaximum effect of free radical scavenging activity against DPPH radicals. There was no significant difference between GLP and Vit-C $(>0.05)$.

In the ERP analysis, the intensity of signal (A.U) decreased with increasing concentration of GLP. So, low concentration of GLP reduces DPPH radicals slowly.

\section{MTT assay}

Figure 7 shows the cytotoxic activity of GLP and doxorubin on MCF-7 cells in dose- and timedependent manner. We examined different concentration of GLP for $48 \mathrm{~h}$ and the effective doses were calculated from dose-response curve. The GLP and DR showed significant activity against MCF-7 cell line with an $\mathrm{IC}_{50} 110.907 \mu \mathrm{g} / \mathrm{mL}$ and $58.206 \mu \mathrm{g} / \mathrm{mL}$ respectively.

\section{Induction of Apoptosis by cell cycle arrest}

The effect of GLP on apoptosis induction in MCF-7 cells was determined using flow cytometry..In this experiments, MCF-7 cells were treated with GLP for $48 \mathrm{~h}$ and then prepared to analyze cell cycle phases. The figure 8 illustrated the viable cells, early-phase apoptotic cells, dead cells and necrotic cells of MCF-7. The early apoptotic cells and dead cells of MCF-7 at $2 \underline{1 x I C}_{50}$ were $18.23 \%$ and $8.45 \%$ respectively(Figure $8 \mathrm{C}$ and $8 \mathrm{D}$ ). At $2 \mathrm{xIC}_{50}, \mathrm{GLP}$ increased the cells in the lower right quadrant and upper right quadrant of MCF-7 to $34.76 \%$ and $16.34 \%$ respectively_(Fig.8A-D). 


\section{Induction of Apoptosis by protein expression}

271 According to figure 8E, the Bcl-2 was down-regulated while Bax gene was up-regulated in

272 treated MCF-7 cells. In addition, GLP induced to increase the expression of Caspase-9. So, GLP

273 significantly increased the expression of Bax and Caspase-9 and suppressed the Bcl-2 in treated

274 MCF-7 cells compared to untreated MCF-7 cells.

275

276

277

278

279

280

281

282

283

284

285

286

287

288

289

290

291

292

293

294

295

296

297

298

299

\section{Discussion}

The present study shows that the polysaccharide extracted from the fruiting bodies of Ganoderma lucidum(GL), termed GLP is homopolysaccharide. The purification of GLP was carried out using DEAE-52 cellulose and Sepharose CL-6B and The purifed polysaccharide was confirmed using UV-Viz and FTIR spectral analysis. GC spectra showed that GLP was a homopolysaccharide. GLP has been shown to consist of D-glucose (Fig.5A and B). The antioxidant homopolysaccharide was confirmed through the DPPH free radical scavenging activities(Fig. 6A and B). Free radicals are derived from normal metabolic processes in the human body and external sources such as industrial chemicals, air pollutants, X-rays, and smoking(20). These are highly reactive species that are capable of damaging biologically significant molecules, such as DNA, proteins, carbohydrates, and lipids(21). Antioxidants can donate an electron to free radicals and neutralize it, resulting delay or inhibit cellular damage(22). Numerous studies have shown that polysaccharides are active mushroom components, which show various pharmacological activities such as antitumor, antioxidant functions(15). In our study, we analyzed and compared DPPH free radicals scavenging activity with that of vitamin C. In DPPH free radical scavenging, it was demonstrated that the $\mathrm{IC}_{50}$ value of GLP was $202.4 \mu \mathrm{g} / \mathrm{ml}$. Furthermore, the antioxidant GLP was used to evaluate the anticancer role in MCF-7 cells line. GLP underwent series of experiments to test their anti-cancer efficacy. Our study was conducted on Breast cancer cells lines. Breast cancer is the most common cancer among women in the world, accounting for 25.4 per cent of the total number of new cases diagnosed in 2018(23). Among breast cancer patients, the average survival of five years was improved by the current treatment methods for patients with breast cancer, but the long-term survival is still poor due to cancer progression and metastasis(24). Breast-conserving surgery, radiation therapy, and mastectomy is the most common treatment for women with early stage 
breast cancer. Phase III patients undergo chemotherapy with mastectomy, while phase IV patients most often receive radiation, chemotherapy and hormonal therapy(24). There are various subtypes of breast cancer; thus different options are selected for the treatment of breast cancer. The use of chemotherapy drugs is usually associated with the production of deleterious side effects and drug resistance for a longer time(25).

Polysaccharides can be useful in this regard because they are nontoxic and commonly found in natural plants(26). Polysaccharides have reported anti-cancer effects from various sources(10). In our study, GLP showed dose- and time-dependent cytotoxic properties against MCF-7 cells (Figure 7). However, the MCF-7 cells were more sensitive to DR $\left(\mathrm{IC}_{50} ; 58.206 \mu \mathrm{g} / \mathrm{mL}\right)$ than the GLP $\left(\mathrm{IC}_{50} ; 110.907 \mu \mathrm{g} / \mathrm{mL}\right)$. The cytotoxic role of GLP is doseand time-dependent. Inhibition of cancer progression often involves the regulation of signal transduction resulting in cell growth arrest and apoptosis. Polysaccharides have been studied in the cell lines of MCF-7 in relation to the protein expression of Bax, Bcl-2 and Caspase-9 in apoptosis (Figure 8E). In this study, GLP showed the upregulation of Bax and Caspase-9 protein expression in MCF-7. Apoptosis characterized for the removal of damaged cells or tumor cells by distinct biochemical factors(27). Apoptosis is an extremely controlled and well maintained cell death cycle during which a cell is subjected to self-destruction(28). In multicellular organisms, it is an important mechanism that removes unnecessary or superfluous cells during growth, or neutralizes potentially harmful cells(29). Apoptosis regulation is essential for the maintenance of natural cellular homeostasis. Nevertheless, apoptosis deregulation has been related to various pathologies such as chronic inflammation, cancer and neurodegenerative diseases(30). Apoptosis is a well defined mechanism that displays distinctive morphological and biochemical characteristics(31). They are distinguished by cell shrinking, membrane blebbing, chromatin condensation and nuclear fragmentation, and by the development of apoptotic bodies digested by macrophages. Apoptotic pathways lead to cysteine dependent aspartate proteases (caspases) being activated(32). Caspase-9 is the initiator caspase linked to the apoptosis intrinsic or mitochondrial pathway(33). When triggered, caspase-9 cleaves and triggers downstream effector caspases 3 and 7, targeting important regulatory and structural proteins for proteolysis to effect cell death(34). Lee et al. reported that the expression level of anti-apoptotic proteins (Bcl2) may be decreased by plant phytochemicals(35). The Bax protein triggers the release of cytochrome $\mathrm{C}$ and other pro-apoptotic proteins into cytosol from the outer mitochondrial 
membrane. Bax further triggers apoptosis initiator Caspase- 9 by the Caspase- 3 cleavage resulting in apoptosis induction(36). From our results, GLP induce apoptosis through the inhibition of Bcl2 protein expression and upstream regulation of Bax and Caspase-9 expression (Figure 8E).

Previous studies have identified a comprehensive relationship between different fractions of polysaccharides from Ganoderma lucidum (10), Lentinus edodes, Lycium barbarum(37), Ganoderma lucidum and Borojoa sorbilis cuter(4) in different models of animals. Our results have concluded that mushroom polysaccharide, as a potential anti-cancer agent for various anticancer treatments, could be employed as the main compound of natural plant products based on the promotion of cell cycle arrest, apoptosis and inhibition of MCF-7 proliferation in vitro. However, earlier studies have identified a comprehensive relationship between different fractions of polysaccharides in various cancer(38). In vivo trials using tested polysaccharide GLP at the next stage will deliver their detailed efficacy study for better anti-cancer prediction.

\section{Conclusion}

Our research aimed to evaluate the apoptosis induction in MCF-7 cells by GLP derived from the Ganoderma lucidum . Because apoptosis has a critical role in the homeostasis of tissues and the prevention of cancer growth, it is now an important goal for cancer treating and preventing the regulation of cell production and the activation of cell apoptosis. GLP was extracted with hot water and further, separation and purification of GLP was carried out using DEAE-52 cellulose and Sepharose CL-6B respectively. GLP was a homo-polysaccharide consisting of D-glucose without protein. According to the degree of purity of GLP was tested and detected by UV-Viz and FTIR spectral analysis. GLP had good antioxidant activity with the $\mathrm{IC}_{50}$ values of 202.4 $\mu \mathrm{g} / \mathrm{mL}$ in DPPH. MTT assay measured the cytotoxicity of GLP, and results showed that GLP significantly inhibited the growth of MCF-7 cells. Such results indicated the GLP could be investigated as a possible anti-tumor agent. The combined data suggest that GLP inhibits the growth of MCF-7 breast cancer cells by inducing the cell cycle arrest and apoptosis. In this study, GLP-induced apoptosis in breast cancer cells demonstrated a dose- and time-dependent manner of activity. GLP induce apoptosis by the down-regulation of Bcl-2 and the up-regulation of Bax and Caspase-9. We assume GLP has the potential anticancer role; more research is needed in animal tumor models to confirm in vivo anti-cancer activity of GLP. 


\section{References}

1. Moussavou G, Kwak DH, Obiang-Obonou BW, Maranguy CA, Dinzouna-Boutamba SD, Lee $\mathrm{DH}$, et al. Anticancer effects of different seaweeds on human colon and breast cancers. (1660-3397 (Electronic)).

2. Jemal A, Bray F Fau - Center MM, Center Mm Fau - Ferlay J, Ferlay J Fau - Ward E, Ward E Fau - Forman D, Forman D. Global cancer statistics. (1542-4863 (Electronic)). 3. Hosseini B-A, Pasdaran A, Kazemi T, Shanehbandi D, Karami H, Orangi M, et al. Dichloromethane fractions of Scrophularia oxysepala extract induce apoptosis in MCF-7 human breast cancer cells. Bosn J Basic Med Sci. 2015;15(1):26-32.

4. Aghbali A, Hosseini Sv Fau - Delazar A, Delazar A Fau - Gharavi NK, Gharavi Nk Fau Shahneh FZ, Shahneh Fz Fau - Orangi M, Orangi M Fau - Bandehagh A, et al. Induction of apoptosis by grape seed extract (Vitis vinifera) in oral squamous cell carcinoma. (1840-4812 (Electronic)).

5. Meng X, Liang H, Luo L. Antitumor polysaccharides from mushrooms: a review on the structural characteristics, antitumor mechanisms and immunomodulating activities. (1873-426X (Electronic)).

6. Pk MMU, O’Sullivan J, Pervin R, Rahman M. Chapter 38 - Antioxidant of Ganoderma lucidum (Jacq.) P. Kumn and lymphoid cancer cells. In: Preedy VR, Patel VB, editors. Cancer (Second Edition). San Diego: Academic Press; 2021. p. 427-37.

7. Shi JJ, Zhang JG, Sun YH, Qu J, Li L, Prasad C, et al. Physicochemical properties and antioxidant activities of polysaccharides sequentially extracted from peony seed dreg. (18790003 (Electronic)).

8. Li N, Li L, Fang J, Wong J, Ng T, Jiang Y, et al. Isolation and identification of a novel polysaccharide-peptide complex with antioxidant, anti-proliferative and hypoglycaemic activities from the abalone mushroom. Bioscience reports. 2011;32:221-8.

9. Friedman M. Mushroom Polysaccharides: Chemistry and Antiobesity, Antidiabetes, Anticancer, and Antibiotic Properties in Cells, Rodents, and Humans. LID 10.3390/foods5040080 [doi] LID - 80. (2304-8158 (Print)).

10. Uddin Pk MM, Islam MS, Pervin R, Dutta S, Talukder RI, Rahman M. Optimization of extraction of antioxidant polysaccharide from Ganoderma lucidum (Jacq.) P. Kumm and its cytotoxic activity against murine lymphoid cancer cell line. PLOS ONE. 2019;14(1):e0209371. 11. Vafaee K, Dehghani S, Tahmasvand R, Saeed Abadi F, Irian S, Salimi M. Potent antitumor property of Allium bakhtiaricum extracts. BMC Complementary and Alternative Medicine. 2019;19(1):116.

12. Chen J, Chen J, Wang X, Liu C. Anti-tumour effects of polysaccharides isolated from Artemisia annua L by inducing cell apoptosis and immunomodulatory anti-hepatoma effects of polysaccharides. African journal of traditional, complementary, and alternative medicines. 2013;11(2505-0044 (Electronic)):15-22.

13. Gao Y, Gao H Fau - Chan E, Chan E Fau - Tang W, Tang W Fau - Xu A, Xu A Fau Yang H, Yang H Fau - Huang M, et al. Antitumor activity and underlying mechanisms of ganopoly, the refined polysaccharides extracted from Ganoderma lucidum, in mice. Immunological investigations. 2005;34(0882-0139 (Print)): 171-98. 
14. Wang J, Hu Y Fau - Wang D, Wang D Fau - Liu J, Liu J Fau - Zhang J, Zhang J Fau Abula S, Abula S Fau - Zhao B, et al. Sulfated modification can enhance the immune-enhancing activity of lycium barbarum polysaccharides. Cellular Immunology. 2010;263(1090-2163 (Electronic)):219-23.

15. Li X, Wang Z, Wang L, Walid E, Zhang H. In vitro antioxidant and anti-proliferation activities of polysaccharides from various extracts of different mushrooms. Int J Mol Sci. 2012;13(5):5801-17.

16. Lowry Oh Fau - Rosebrough NJ, Rosebrough Nj Fau - Farr AL, Farr Al Fau - Randall RJ, Randall RJ. Protein measurement with the Folin phenol reagent. (0021-9258 (Print)).

17. Jain VM, Karibasappa GN, Dodamani AS, Mali GV. Estimating the carbohydrate content of various forms of tobacco by phenol-sulfuric acid method. J Educ Health Promot. 2017;6:90-.

18. Li X, Zhao R, Zhou HL, Wu DH. Deproteinization of Polysaccharide from the Stigma Maydis by Sevag Method. Advanced Materials Research. 2012;340:416-20.

19. Nithianantham K, Shyamala M Fau - Chen Y, Chen Y Fau - Latha LY, Latha Ly Fau Jothy SL, Jothy Sl Fau - Sasidharan S, Sasidharan S. Hepatoprotective potential of Clitoria ternatea leaf extract against paracetamol induced damage in mice. (1420-3049 (Electronic)). 20. Cheeseman KH, Slater TF. An introduction to free radical biochemistry. (0007-1420 (Print)).

21. Phaniendra A, Jestadi DB, Periyasamy L. Free radicals: properties, sources, targets, and their implication in various diseases. (0970-1915 (Print)).

22. Hertog MG, Feskens Ej Fau - Hollman PC, Hollman Pc Fau - Katan MB, Katan Mb Fau Kromhout D, Kromhout D. Dietary antioxidant flavonoids and risk of coronary heart disease: the Zutphen Elderly Study. (0140-6736 (Print)).

23. Bray F, Ferlay J, Soerjomataram I, Siegel RL, Torre LA, Jemal A. Global cancer statistics 2018: GLOBOCAN estimates of incidence and mortality worldwide for 36 cancers in 185 countries. (1542-4863 (Electronic)).

24. Miller KA-O, Nogueira L, Mariotto AB, Rowland JH, Yabroff KR, Alfano CA-O, et al. Cancer treatment and survivorship statistics, 2019. CA: a cancer journal for clinicians. 2019;69(1542-4863 (Electronic)):363-85.

25. Housman G, Byler S, Heerboth S, Lapinska K, Longacre M, Snyder N, et al. Drug resistance in cancer: an overview. (2072-6694 (Print)).

26. Chen J, Chen J, Wang X, Liu C. Anti-tumour effects of polysaccharides isolated from Artemisia annua L by inducing cell apoptosis and immunomodulatory anti-hepatoma effects of polysaccharides. Afr J Tradit Complement Altern Med. 2013;11(1):15-22.

27. Hou DX, Tong X Fau - Terahara N, Terahara N Fau - Luo D, Luo D Fau - Fujii M, Fujii M. Delphinidin 3-sambubioside, a Hibiscus anthocyanin, induces apoptosis in human leukemia cells through reactive oxygen species-mediated mitochondrial pathway. (0003-9861 (Print)). 28. Kerr Jf Fau - Wyllie AH, Wyllie Ah Fau - Currie AR, Currie AR. Apoptosis: a basic biological phenomenon with wide-ranging implications in tissue kinetics. (0007-0920 (Print)). 29. Redza-Dutordoir M, Averill-Bates DA. Activation of apoptosis signalling pathways by reactive oxygen species. (0006-3002 (Print)).

30. Fulda S, Gorman AM, Hori O, Samali A. Cellular Stress Responses: Cell Survival and Cell Death. International Journal of Cell Biology. 2010;2010:214074.

31. Elmore S. Apoptosis: a review of programmed cell death. (0192-6233 (Print)).

32. Shalini S, Dorstyn L, Dawar S, Kumar S. Old, new and emerging functions of caspases. (1476-5403 (Electronic)). 


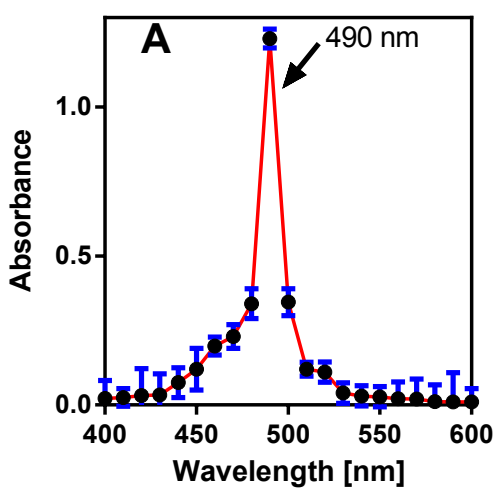
cellular level. (1471-0080 (Electronic)). Immunology. 2010;263(2):219-23. 1344 (Electronic)). concentration $(\mathrm{mg} / \mathrm{mL})$.

33. Budihardjo I, Oliver H Fau - Lutter M, Lutter M Fau - Luo X, Luo X Fau - Wang X, Wang X. Biochemical pathways of caspase activation during apoptosis. (1081-0706 (Print)). 34. Taylor RC, Cullen Sp Fau - Martin SJ, Martin SJ. Apoptosis: controlled demolition at the

35. Moussavou G, Kwak DH, Obiang-Obonou BW, Maranguy CA, Dinzouna-Boutamba SD, Lee DH, et al. Anticancer effects of different seaweeds on human colon and breast cancers. Marine Drugs. 2014;24(12(9)):4898-911. 36. Lu M-K, Cheng J-J, Lin C-Y, Chang C-C. Purification, structural elucidation, and antiinflammatory effect of a water-soluble 1,6-branched 1,3- $\alpha$-d-galactan from cultured mycelia of Poria cocos. Food Chemistry. 2010;118(2):349-56.

37. Wang J, Hu Y, Wang D, Liu J, Zhang J, Abula S, et al. Sulfated modification can enhance the immune-enhancing activity of lycium barbarum polysaccharides. Cellular

38. Xu F, Liao K, Wu Y, Pan Q, Wu L, Jiao H, et al. Optimization, characterization, sulfation and antitumor activity of neutral polysaccharides from the fruit of Borojoa sorbilis cuter. (1879-

Figure 1. (A) Absorbance validation of D-Glucose (range: 400-600 nm) (B) The standard curve of D-glucose (Abs. at $490 \mathrm{~nm}$ ). $\mathrm{Y}$ axis shows the absorbance and $\mathrm{X}$ axis shows the glucose

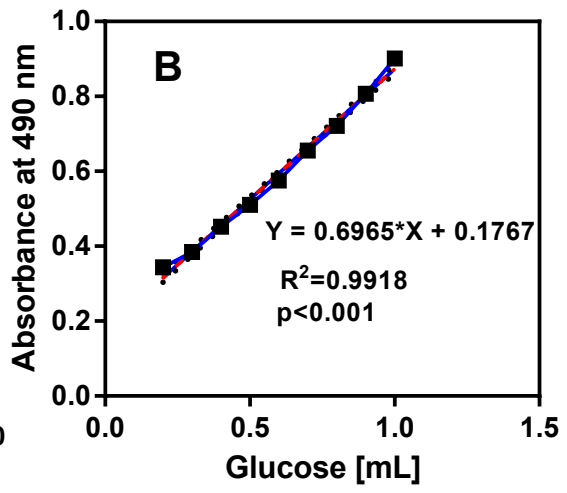


475

476

477

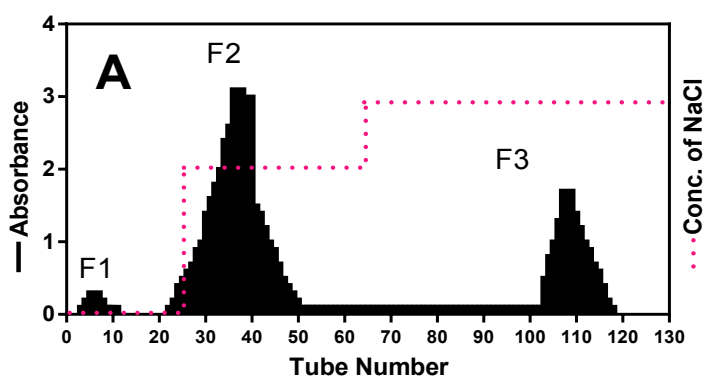

478

479

480

481

482

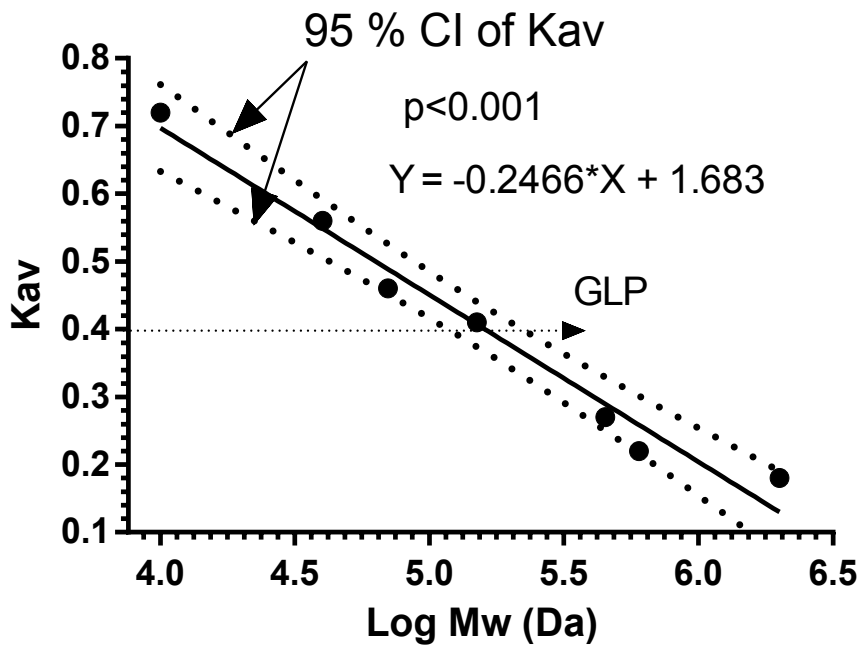
Ganoderma lucidum polysaccharide Ganoderma lucidum based on Kav.

Figure 2. Elution profile of GLP (A) DEAE-52 column and (B) Sephadex S-300 column. GLP;

Figure 3. Standard curve of dextran series for the determination of $\mathrm{Mw}$ of the polysaccharide of 
bioRxiv preprint doi: https://doi org/10.1101/2022 01.04.474971. this version posted January 4, 2022. The copyright holder for this preprint (which was not certified by peer review) is the author/funder, who has granted bioRxiv a license to display the preprint in perpetuity. It is made available under aCC-BY 4.0 International license.
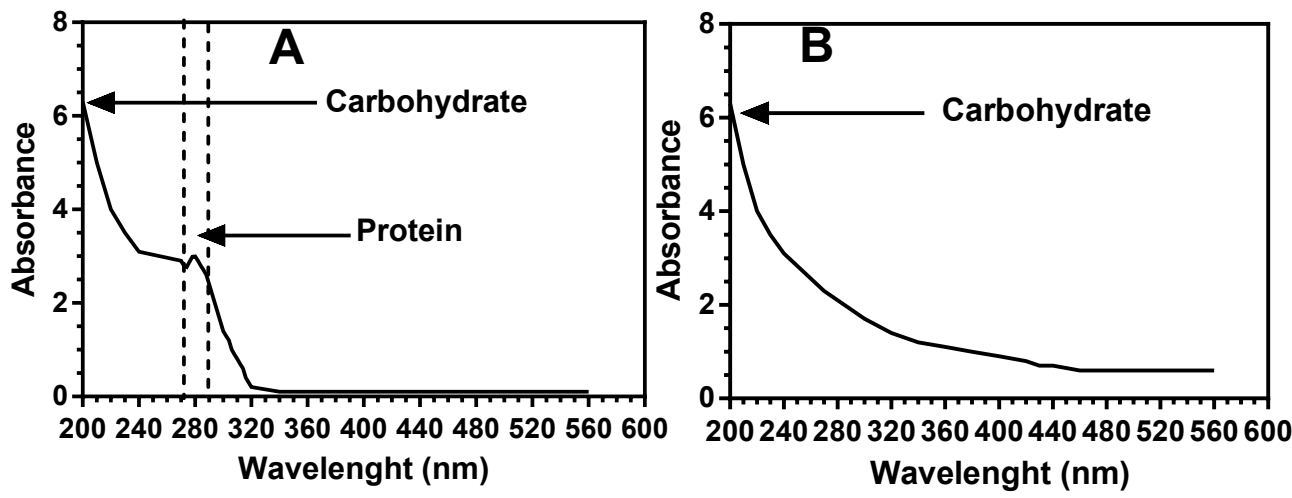

493

494

495 
Figure 5. Monosaccharide compositions and FT-IR analysis of GLP. (A) GC results of standard

507 momosaccharides, (B) GC spectra of GLP fraction, and (C) FT-IR spectra of GLP. D-Man; D-

508 Mannose, D-Glu; D-Glucose; and D-Gal; D-Galactose. GLP; Ganoderma lucidum
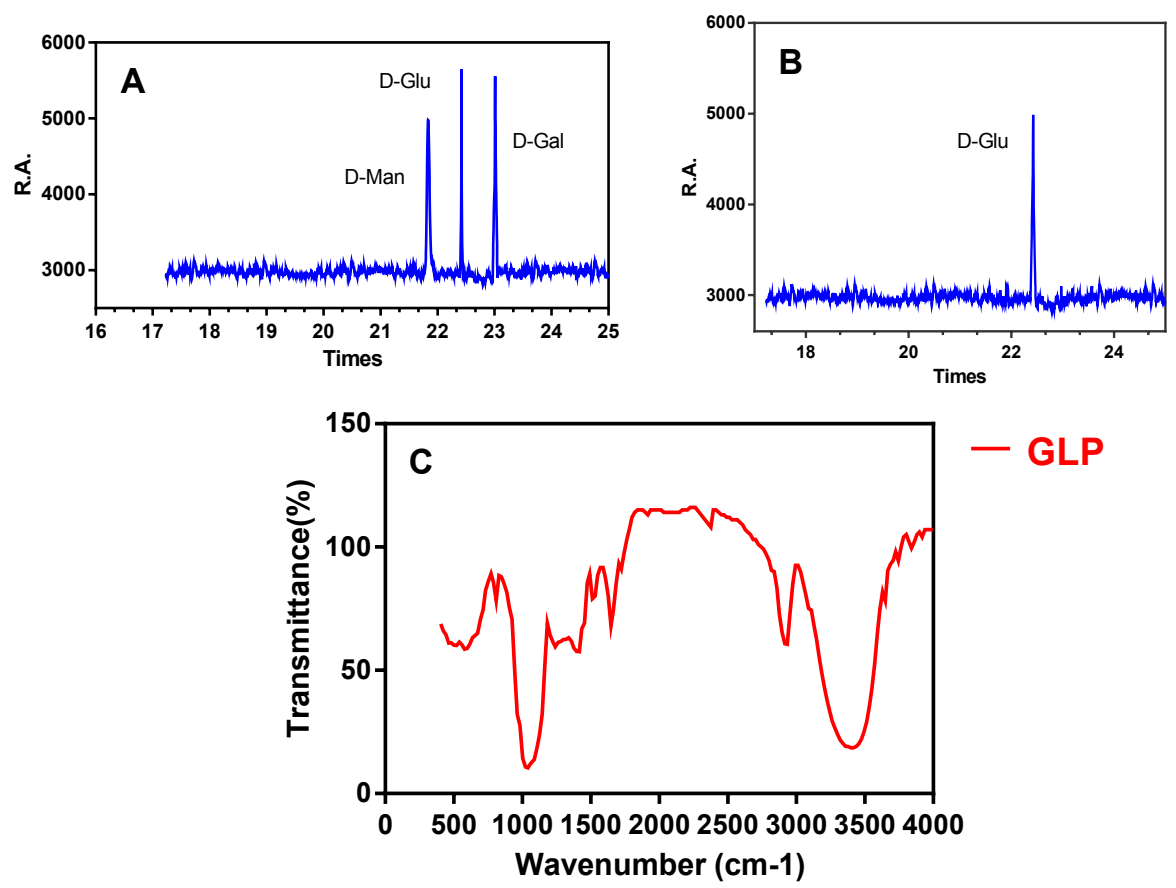
Figure 6. (A) Dose-response curve (B) UV-Viz absorbance intensity of treated and untreated
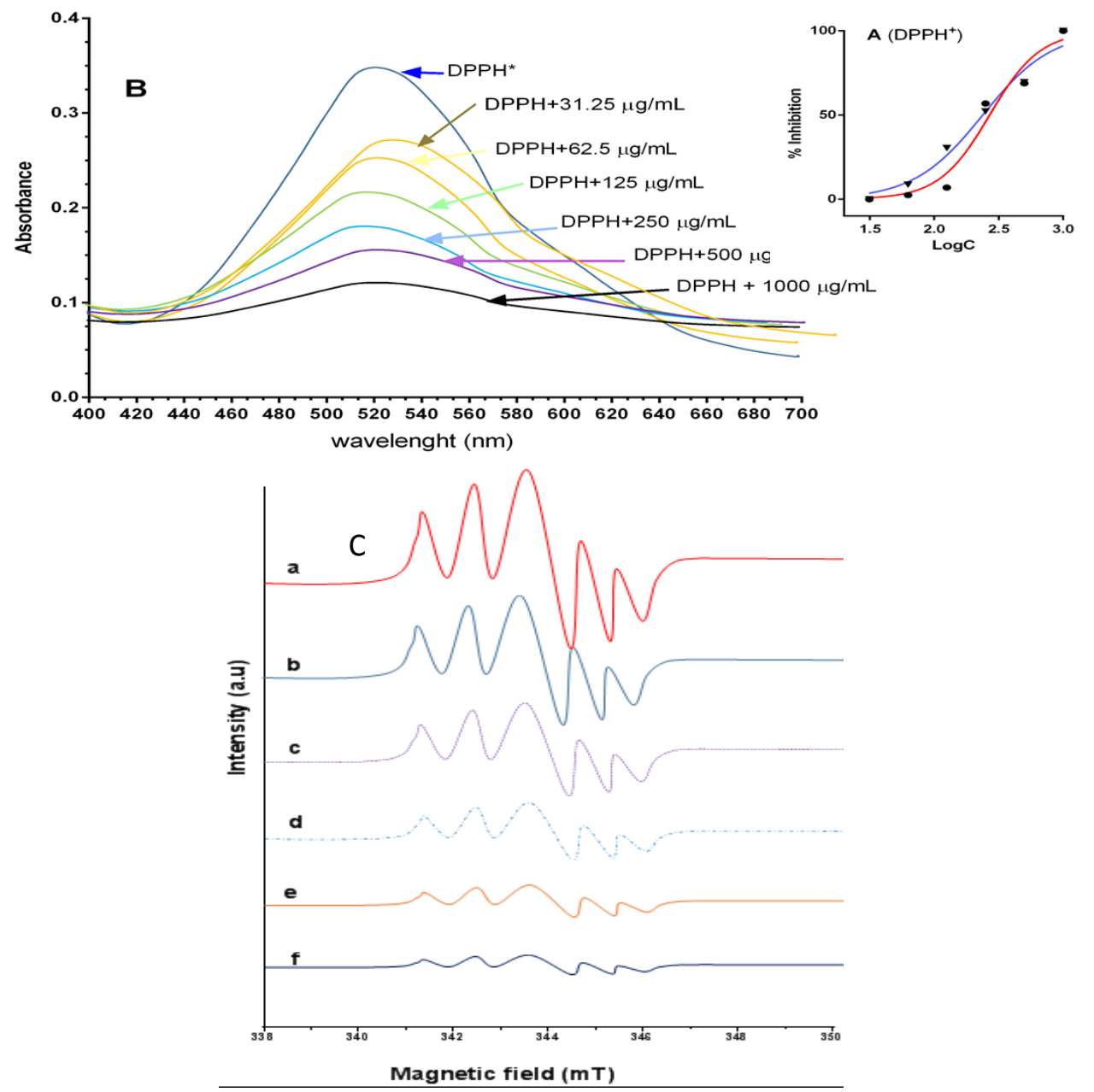
529 Figure 7. Inhibition of MCF-7 cell proliferation by GLP and DR. GLP-Ganoderma lucidum

530 polysaccharide, DR-Doxorubin

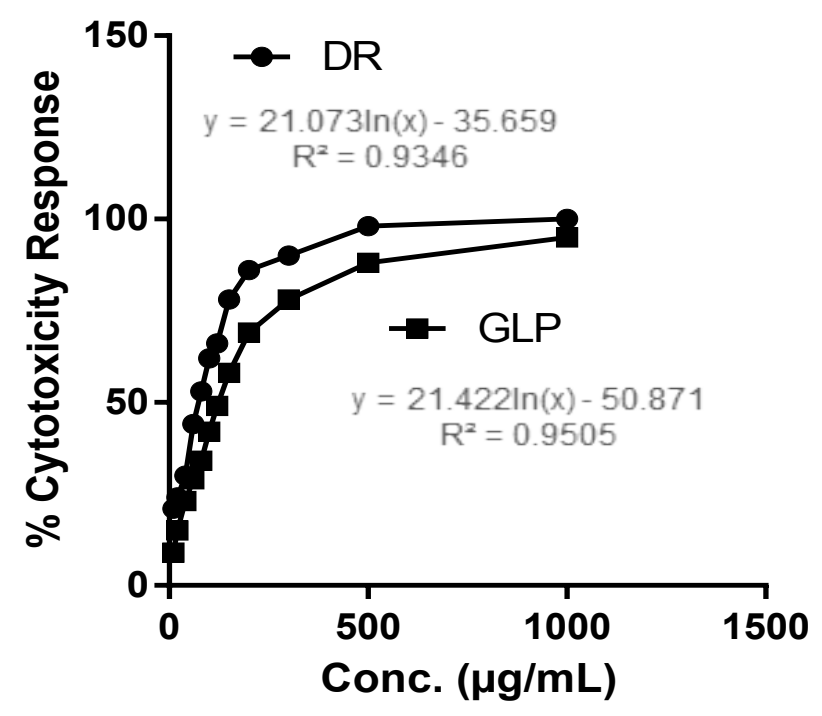


545 Figure 8. Cell cycle phases distribution of MCF-7 cells using flow cytometry analysis. (A) GLP,

$5461 \times \mathrm{IC}_{50}$ (B) GLP, $2 \times \mathrm{IC}_{50}$ (C) Cell count for $1 \times \mathrm{IC}_{50}$ GLP (D) Cell count for $2 \times \mathrm{IC}_{50}$ GLP and

547 (E) Apoptotic protein expression of Bcl-2, Bax, and Caspase-9 induced by GLP at $2 \times \mathrm{IC}_{50}$ on

$548 \quad \mathrm{MCF}-7$ cells.

549

550
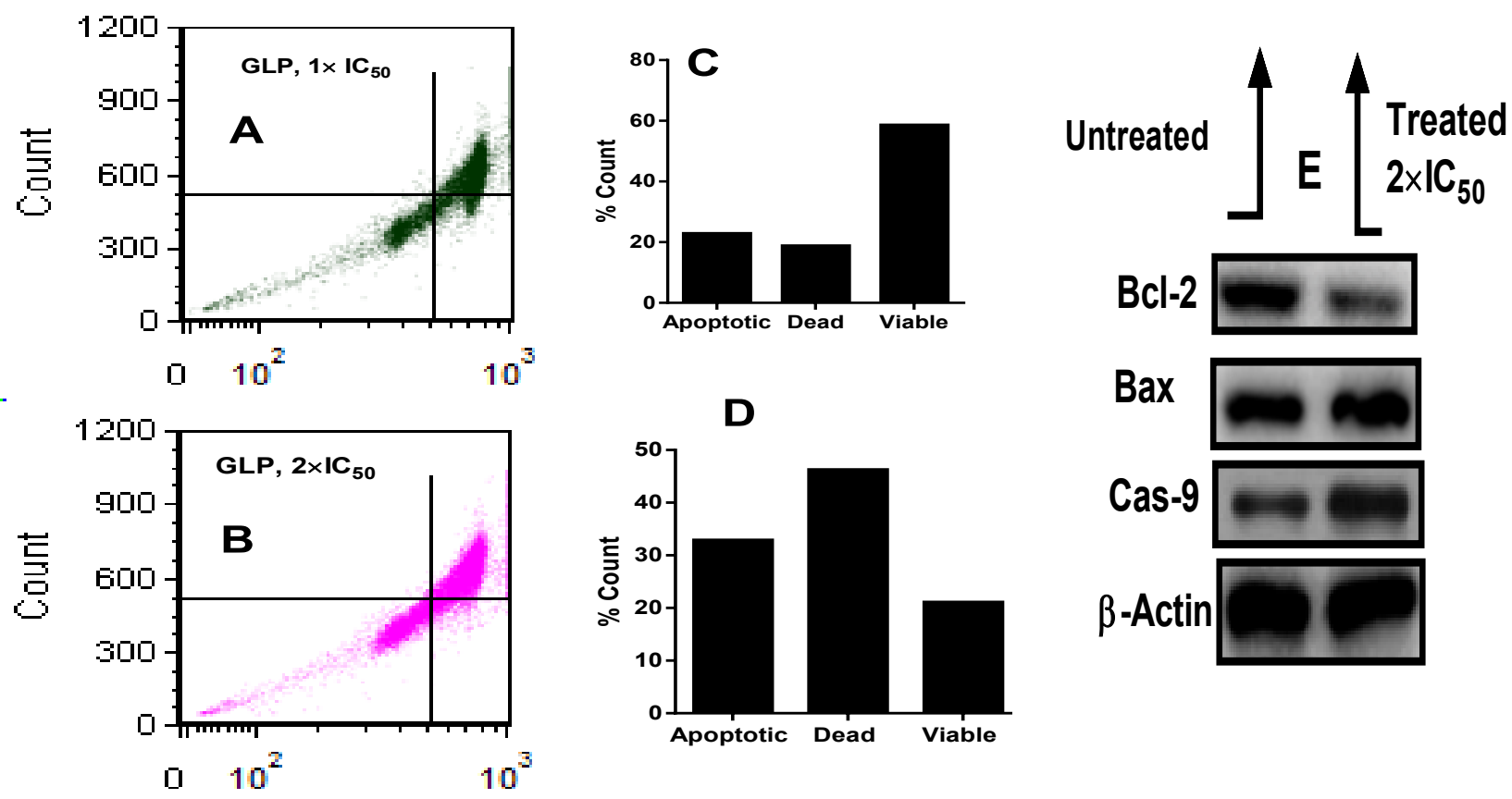

$\beta-A c t i n$

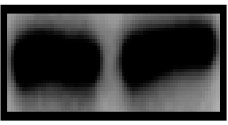

